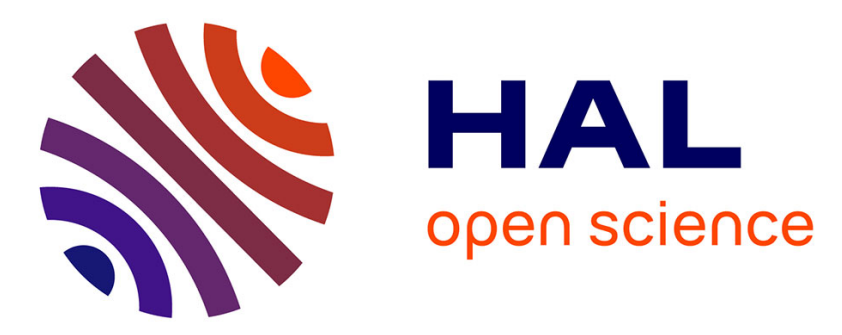

\title{
Embolism induced by winter drought may be critical for the survival of Pinus sylvestris L. near its southern distribution limit
}

José Peguero-Pina, José Alquézar-Alquézar, Mayr, Cochard, Gil-Pelegrín

\section{- To cite this version:}

José Peguero-Pina, José Alquézar-Alquézar, Mayr, Cochard, Gil-Pelegrín. Embolism induced by winter drought may be critical for the survival of Pinus sylvestris L. near its southern distribution limit. Annals of Forest Science, 2011, 68 (3), pp.565-574. 10.1007/s13595-011-0068-0 . hal-00930802

\section{HAL Id: hal-00930802 https://hal.science/hal-00930802}

Submitted on 1 Jan 2011

HAL is a multi-disciplinary open access archive for the deposit and dissemination of scientific research documents, whether they are published or not. The documents may come from teaching and research institutions in France or abroad, or from public or private research centers.
L'archive ouverte pluridisciplinaire HAL, est destinée au dépôt et à la diffusion de documents scientifiques de niveau recherche, publiés ou non, émanant des établissements d'enseignement et de recherche français ou étrangers, des laboratoires publics ou privés.

$$
\text { Copyright }
$$




\title{
Embolism induced by winter drought may be critical for the survival of Pinus sylvestris $L$. near its southern distribution limit
}

\author{
José Javier Peguero-Pina • \\ José María Alquézar-Alquézar • Stefan Mayr • \\ Hervé Cochard • Eustaquio Gil-Pelegrín
}

Received: 27 April 2010 / Accepted: 1 October 2010/Published online: 10 May 2011

(C) INRA and Springer Science+Business Media B.V. 2011

\begin{abstract}
- Introduction Scots pine populations in the SE "Sistema Ibérico" range suffered a severe defoliation in the S face of the crown in isolated trees of thinned stands. This process was detected at the end of the winter 2001-2002.

- Aim We hypothesise that winter conditions may be as critical for Scots pine survival as summer drought, even for these southern populations. In this way, the possible connection between the microclimate conditions and the risk of xylem embolism during the winter of 2001-2002 was analysed.

- Discussion The additional decrease in water potential found in the affected trees could be caused by the combination of (1) low soil temperatures limiting water uptake by roots, (2) a higher vulnerability to drought-induced embolism due to the occurrence of repeated freeze-thaw cycles, and (3) high radiation events throughout the winter, increasing the loss of water by transpiration. Thus, the additional induction of embolism found in the affected trees (ca. 27\%) could be caused by the combination of these factors.
\end{abstract}

\author{
Handling Editor: Erwin Dreyer \\ J. J. Peguero-Pina · J. M. Alquézar-Alquézar • E. Gil-Pelegrín $(\bowtie)$ \\ Forest Resources Unit, Centro de Investigación y Tecnología \\ Agroalimentaria, Gobierno de Aragón, \\ Avda. Montañana 930, \\ 50059 Zaragoza, Spain \\ e-mail: egilp@aragon.es \\ S. Mayr \\ Department of Botany, University of Innsbruck, \\ A-6020 Innsbruck, Austria \\ H. Cochard \\ INRA, UMR PIAF, \\ Crouel, \\ 63100 Clermont-Ferrand, France
}

- Conclusion Estimated conditions during winter 20012002 were extremely unfavourable, leading probably to an impaired water status and high embolism rates, which may have induced the severe defoliation observed in crowns of affected trees.

Keywords Cavitation · Drought · Freeze-thaw $\cdot$ Leaf-to-air temperature difference $\cdot$ Scots pine

\section{Introduction}

Scots pine (Pinus sylvestris L.) in Spain reaches the southern limit of its wide natural range (Poyatos et al. 2007), probably due to the migrational process of the species during the Holocene (Cheddadi et al. 2006). The current distribution of Scots pine in the Iberian Peninsula is always associated to the existence of high mountain ranges, where climatic conditions are topographically modulated. This fact implies that Scots pine is restricted to a specific altitudinal range in these areas (Alía et al. 2001; Cañellas et al. 2000). In fact, Scots pine populations in the south-eastern "Sistema Ibérico" range $\left(40^{\circ} 25^{\prime} \mathrm{N}\right.$, Teruel province, Spain) are located from 1,500 upwards to $1,900 \mathrm{~m}$ above sea level, mainly over calcareo-dolomitic lithologies (Cañellas et al. 2000). These populations are living under conditions typical for the "arid altitudinal belts" in the mountains of the Mediterranean area (Breckle 2002), which are characterised by the existence of a long frost period and a summer drought noticeable up to the alpine zones. Furthermore, annual precipitation values range from 450 to $600 \mathrm{~mm}$, with a great inter-annual variability (Querol 1995).

Under such climatic conditions, which are very different from those existing in the main distribution 
area of Scots pine (Andersson and Fedorkov 2004), the growing period is reduced to just a short part of the year due to the combination of summer drought and winter frost. The importance of summer drought in these southern Scots pine populations has led to consider that any increase in aridity in the Mediterranean region may induce the extinction of this species in this area (Poyatos et al. 2008). In fact, several authors reported high mortality rates associated with recent extreme summer drought episodes in several Scots pine populations in Spain during last decades (MartínezVilalta and Piñol 2002). If severe episodes of summer drought have been revealed to be critical for the survival of these southern Scots pine populations, further studies should be addressed to handle the importance of episodes of winter drought occurring at these altitudinal areas of the Iberian Peninsula.

Winter temperatures can impair the hydraulic functions of the trees because water uptake from soil water reservoirs is very limited when upper soil layers are cool or frozen during winter months or early spring (Mellander et al. 2006). In fact, transpiration is restricted in Scots pine at soil temperatures below $+8^{\circ} \mathrm{C}$ (Mellander et al. 2004), probably due to a decrease in root permeability (Cochard et al. 2002; Schwarz et al. 1997). Moreover, the occurrence of freeze-thaw events can cause additional long-term effects in the hydraulic functions of the tree by the induction of embolism (Mayr et al. 2006). Freezing of the conducting elements leads to the formation of gas bubbles, which can expand during thawing when the bubble diameter exceeds a critical size and the xylem water potential is low (Pittermann and Sperry 2003). Although Feild and Brodribb (2001) indicated a high resistance of conifers to freeze-thawinduced embolism, the combined stress of low water potentials and a high number of freeze-thaw events are sufficient to induce embolism (Mayr et al. 2002, 2003b, 2007), even in species with narrow tracheids (Pittermann and Sperry 2003, 2006). Irrespective of these direct and indirect effects of low temperatures on the water balance of the trees, which are common to the high mountains of mid-latitude areas, southern Europe experiences winter episodes of high solar radiation during the positive phase of the North Atlantic Oscillation (NAO; Pozo-Vázquez et al. 2004). The reduction of cloud cover throughout the winter may have a direct effect on air and needle temperatures, affecting the leaf-to-air vapour pressure gradient and, as a consequence, the water transpired by the plant (Hadley and Smith 1987). Although it has been commonly assumed that conifer needle temperature seldom, if ever, differs from air temperature (Jarvis et al. 1976), Martin et al. (1999) showed that leaf temperature can become substantially higher than air when radiation is high in a conifer species, especially when stomatal conductance is very low, as occurs during winter. This fact, in combination with an impediment of water uptake when upper soil layers are cool or frozen, causes a decrease in water content and potential (Mayr et al. 2002, 2003b).

Winter drought might be the causing factor that could explain the recent episode of massive damage suffered by these southern Scots pine populations, which was detected at the end of the winter of 2001-2002. This episode was characterised by needle yellowing followed by severe defoliation and whole branch death, mainly in the $\mathrm{S}$ face of the crown in isolated trees of thinned stands. We hypothesise that winter conditions may be as critical for Scots pine survival as summer drought, even for these southern populations. Thus, the ultimate explanation for this phenomenon may be a combination of (1) low soil temperatures limiting water uptake by roots, (2) a higher vulnerability to drought-induced embolism due to the occurrence of repeated freeze-thaw cycles, and (3) high radiation events throughout the winter, increasing the loss of water by transpiration. For this purpose, we carried out a comparison of key water relation parameters (water potential, hydraulic conductivity and embolism rate) and microclimate measurements during one winter season. Based on these measurements and the climatic data of previous years, we analysed the possible connection between the microclimate conditions and the risk of xylem embolism during the winter of 2001-2002.

\section{Materials and methods}

\subsection{Study site}

The population of Scots pine selected for the study is located in the southern "Sistema Ibérico" range $\left(40^{\circ} 30^{\prime} \mathrm{N}\right.$, $0^{\circ} 36^{\prime}$ E, 1650 ma.s.l., Teruel, Spain). Mean annual precipitation recorded in the nearby meteorological station during the period 1997-2003 was $510 \pm 21 \mathrm{~mm}$. This population is over degraded soils characterised by the presence of superficial calcareous substrates that are only $10-30 \mathrm{~cm}$ in depth. In this study, we distinguished two kinds of trees: (1) trees without any symptom of defoliation (thereafter, unaffected trees) and (2) trees with evident symptoms of defoliation in the $\mathrm{S}$ face of the crown (thereafter, affected trees; Fig. 1). Physiological measurements were carried out in 5-6-year-old branches located in the $\mathrm{S}$ face of the crown from 25 co-dominant affected and unaffected trees, randomly selected. In case of affected trees, we selected branches with a high degree of defoliation but still maintaining living needles evenly distributed along the branch. 


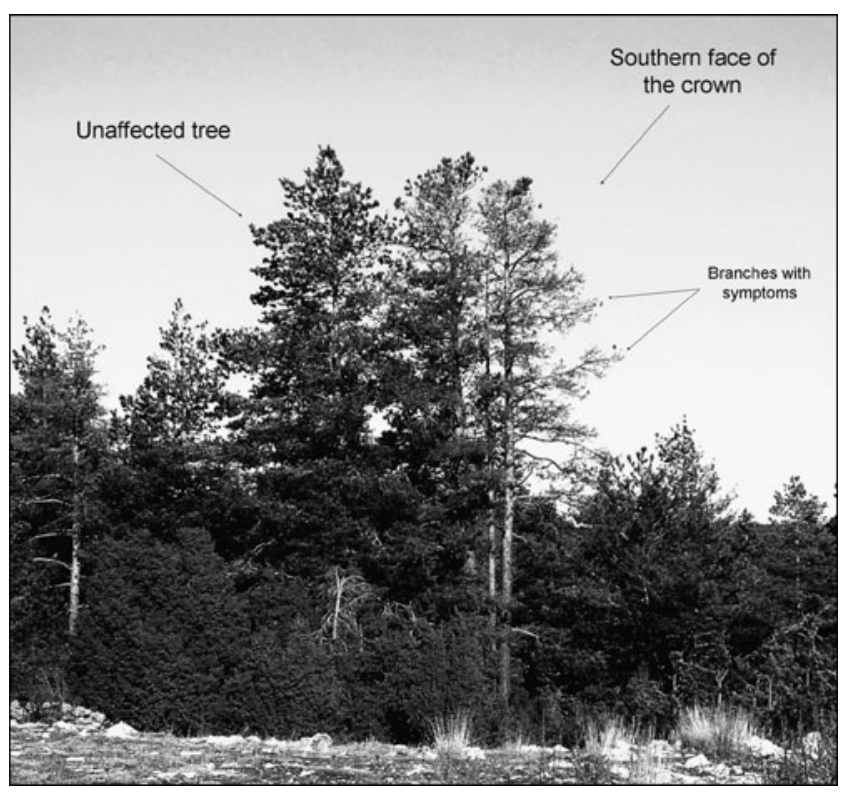

Fig. 1 An example of the unaffected (without any symptom of defoliation) and affected (with evident symptoms of defoliation in the $\mathrm{S}$ face of the crown) Scots pine trees used in this study

\subsection{Water potential}

Water potential (-megapascals) was measured at midday on about $10-\mathrm{cm}$-long end segments of twigs from three southexposed branches per tree, collected from five affected and five unaffected trees of the studied Scots pine population. Measurements were carried out with a Scholander-type pressure chamber, following the methodological procedures described by Turner (1988), twice a month from August 2005 until November 2006.

\subsection{Temperature measurements}

The nearby meteorological station was located at Villarroya de los Pinares $\left(40^{\circ} 31^{\prime}\right.$ N, $0^{\circ} 40^{\prime} \mathrm{W}, 1337$ ma.s.l., 1995-2008 period), which reported values of maximum and minimum daily temperatures. The straight line distance between

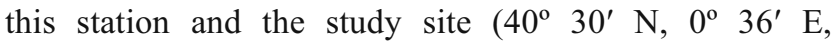
1650 ma.s.1.) was ca. $6 \mathrm{~km}$, and the difference in altitude was $313 \mathrm{~m}$. In order to use the data from this station to reconstruct the meteorological conditions in the study site during the previous years, we had to register the meteorological conditions in the study site and, subsequently, establish correlations with the data from the nearby meteorological station.

Temperatures in the study site were measured at 10min intervals and stored by a data logger (CR1000, Campbell Scientific, USA) from June 2006 until June 2008. Needle and stem temperatures were taken with three type $T$ thermocouples per tree, placed at south- exposed branches of three trees from the studied Scots pine population. Thermocouples were covered with PVC and attached to the tree with adhesive aluminium tape in order to avoid the exposure to direct solar radiation. Air temperatures were taken with three thermocouples mounted on the top of each studied tree, located inside a solar shield. Moreover, soil temperatures were taken by placing three thermocouples per tree at soil depths of 10 and $20 \mathrm{~cm}$, respectively.

To estimate the temperatures in the studied Scots pine population, linear regression models were used to correlate temperature data from the nearby meteorological station and those obtained with the data logger in the study site from November to March. The regression models obtained were:

$$
T_{\operatorname{maxSS}}=1.098 T_{\max \mathrm{MS}}-2.367\left(R^{2}=0.85, P<0.05\right)
$$

$$
T_{\operatorname{minSS}}=1.005 T_{\min \mathrm{MS}}+1.763\left(R^{2}=0.96, P<0.05\right)
$$

where $T_{\max }$ ss and $T_{\min }$ ss are the maximum and minimum daily temperatures measured in the study site, and $T_{\max }$ MS and $T_{\min }$ MS are the maximum and minimum daily temperatures in the nearby meteorological station. Based on these correlations, we estimated air, needle and stem temperatures during winter 2001/2002 and the previous five winters (from 1996-1997 to 2000-2001).

Freezing-thawing events were estimated from stem temperature data. Freezing events were counted when the stem temperatures decreased from above $0^{\circ} \mathrm{C}$ to below $-2^{\circ}$ $\mathrm{C}$, while thawing events were counted when temperatures increased from lower than $-2^{\circ} \mathrm{C}$ above $0^{\circ} \mathrm{C}$ (Mayr et al. 2006). Moreover, we calculated the frequency distribution (percent) of daily maximum rates of increasing stem temperature (Kelvin per hour) rates in the days with freeze-thaw cycles.

\subsection{Solar radiation and relative air humidity measurements}

Relative humidity (RH, percent) and solar radiation (watts per square metre) were measured at 10-min intervals and stored by a data logger (CR1000, Campbell Scientific, USA) from June 2006 until June 2008. RH was taken using three RH probes (HMP45C, Campbell Scientific, USA) housed in MET21 radiation shields for optimum reading accuracy. Solar radiation was taken using three silicon pyranometers (CS300, Campbell Scientific, USA). Moreover, RH, air and needle temperature data were used to calculate the leaf-to-air water vapour pressure difference (LAVPD, kilopascals), assuming $100 \% \mathrm{RH}$ within the needle (Anfodillo et al. 2002). 
Fig. 2 Seasonal courses of daily maximum a air temperature (degrees Centigrade), b stem temperature (degrees Centigrade), c solar radiation (watts per square metre), and $\mathbf{d}$ relative humidity $(\mathrm{RH}$, percent) during winter $2007 / 2008$ at the studied Scots pine population

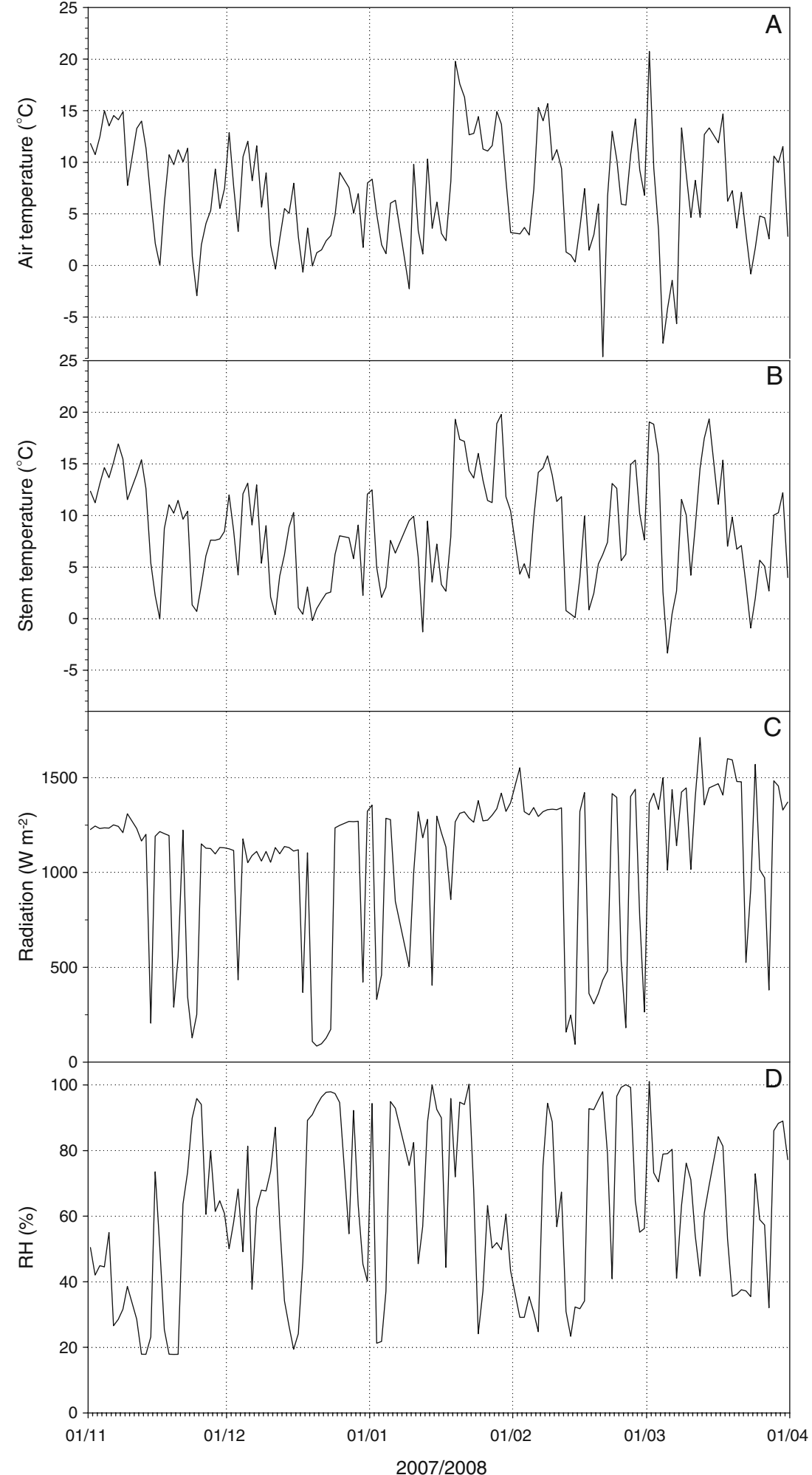

2.5 Measurement of hydraulic conductivity and embolism rates

We measured the hydraulic conductivity of stem segments obtained from ten south-exposed branches (1.5-
$2 \mathrm{~m}$ long) from affected trees and ten south-exposed branches (1.5-2 $\mathrm{m}$ long) from unaffected trees of the studied Scots pine population. One branch per tree were collected at March (just after snow melting) and the different stem segments (5-6 years old, 3-7 cm long and 
up to $2.5 \mathrm{~cm}$ in diameter, four segments per branch) prepared as described in Mayr et al. (2002). Measurements were made during 2007 in 5-6-year-old stem segments because we suspected embolism may have occurred during winter 2001/2002 (6 years before the measurements were carried out). Measurement pressure was set to 4 kilopascals. The flow rate was determined with a PC-connected balance (Sartorius BP221S, $0.1 \mathrm{mg}$ precision, Sartorius AG, Göttingen, Germany) by recording weight every $10 \mathrm{~s}$ and fitting linear regressions over 200-s intervals. Conductivity measurements were done with distilled, filtered $(0.22 \mu \mathrm{m})$, and degassed water containing 0.005\% ( $v / v)$ "Micropur" (Katadyn Products, Wallisellen, Switzerland) to prevent microbial growth (Mayr et al. 2006). Samples from unaffected trees were used to confirm that this Scots pine population followed the model which relates the sample diameter and the saturated hydraulic conductivity (after refilling) proposed by Cochard (1992) for this species.

Percent loss of conductivity (PLC) was calculated following the methodology described in Mayr and Cochard (2003). After removal of the bark and recutting under water, samples were sealed in silicone tubes connected to a reservoir filled with dye solution (phloxine B, Sigma Chemical, 2\% $(w / v))$. After staining (4 kilopascals, 5-10 min), sample cross-sections were prepared, and PLC was calculated as the ratio between the area that was not dyed by phloxine $\mathrm{B}$ and the total area of the sample cross-section.

\subsection{Statistical analysis}

Differences in microclimate measurements between 2001/2002 and the period 1996/1997-2001/2002 were tested at 5\% probability level with paired Student's $t$ test. Differences in water potential and PLC between affected and unaffected trees were tested at 5\% probability level with paired Student's $t$ test after checking for normal distribution and variance of the data. Correlation analyses were carried out via Pearson's linear correlation coefficient $r$ at 5\% probability level.

\section{Results}

\subsection{Microclimate measurements}

The daily maximum air and stem temperatures (degrees Centigrade) during winter 2007/2008 at the studied Scots pine population are shown in Fig. 2a, b, respectively. Both temperatures experience a sharp increase since the end of January. It is necessary to emphasise that there is an episode from the end of January to the beginning of February that
Fig. 3 Seasonal courses of soil temperatures 2007/2008 at $10 \mathrm{~cm}$ depth (upper panel) and $20 \mathrm{~cm}$ depth (lower panel) taken every $10 \mathrm{~min}$ at the studied Scots pine population

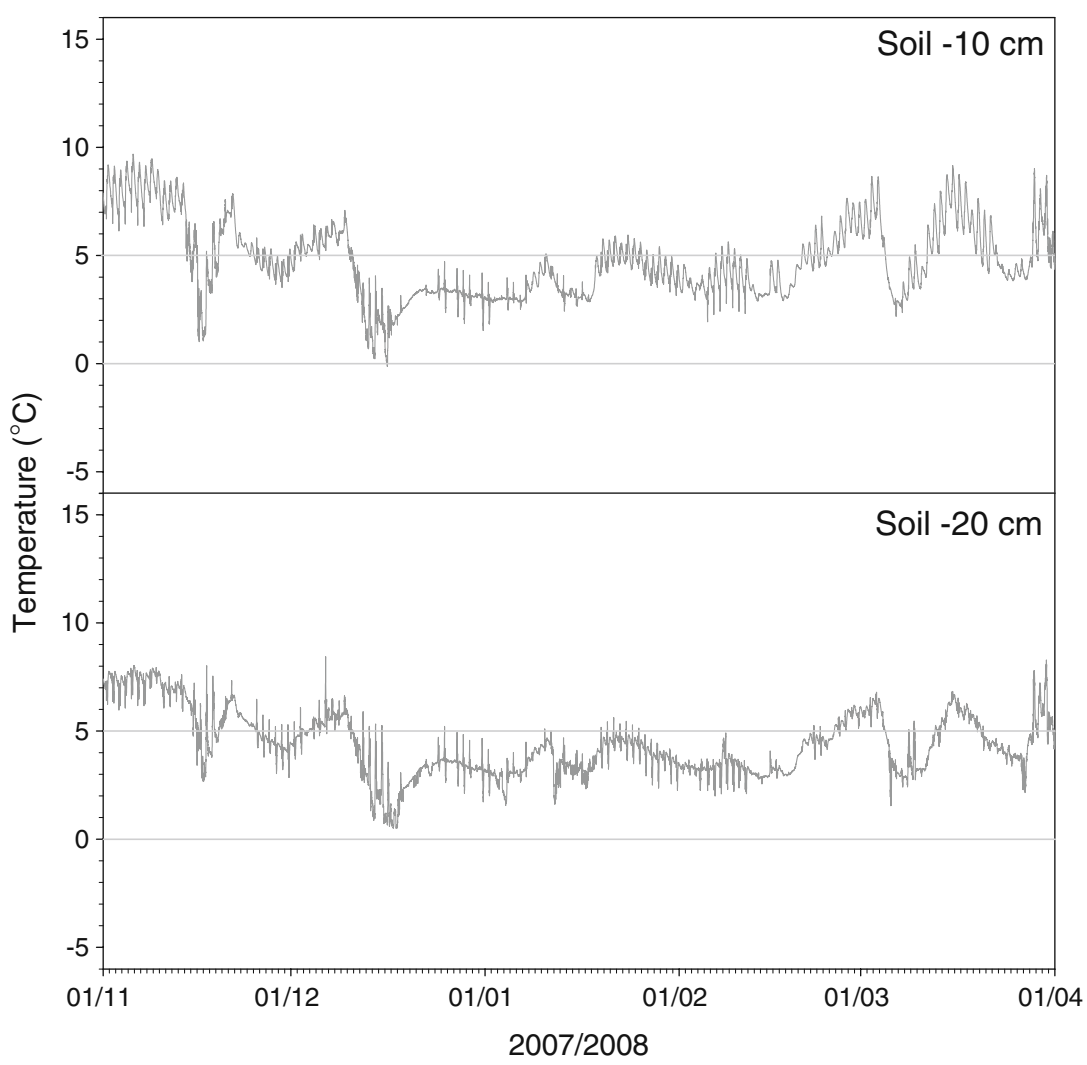


coincides with several consecutive days with high values of daily maximum solar radiation (Fig. 2c) and low values of daily minimum RH (Fig. 2d). Figure 3 shows the seasonal courses of soil temperatures during the winter 2007/2008 at 10 and $20 \mathrm{~cm}$ depth, which are below $5^{\circ} \mathrm{C}$ from December to March.

Figures $4 \mathrm{a}, \mathrm{b}$ show, respectively, the leaf-to-air temperature difference (LATD, degrees Centigrade) and the LAVPD (kilopascals) during winter 2007/2008 in southexposed branches of the studied Scots pine population. These parameters show their maximum values at the end of the winter and the beginning of the spring, when soil temperature is still below $5^{\circ} \mathrm{C}$ (Fig. 3). The maximum
LAVPD value during this period (1.88 kilopascals) occurs at the end of January, which coincides with the period of several consecutive days with high rates of solar radiation and low values of RH (Fig. 2c, d). Furthermore, Fig. 4c shows the frequency distribution (percent) of daily maximum rates of increasing stem temperature rates (Kelvin per hour) at days with freeze-thaw cycles.

The microclimate data measured during winter 2007/ 2008 have been used to reconstruct the meteorological conditions in the study site during the previous years, establishing correlations with the data from the nearby meteorological station (see section 2.3 for details). Estimated daily maximum temperatures of south-exposed
Fig. 4 a Leaf-to-air temperature difference (LATD, degrees Centigrade), b leaf-to-air water vapour pressure difference (LAVPD, kilopascals) and c frequency distribution (percent) of daily maximum rates of the temperature increase (Kelvin per hour) at days with freezethaw cycles during winter $2007 / 2008$ in south-exposed branches of the studied Scots pine population
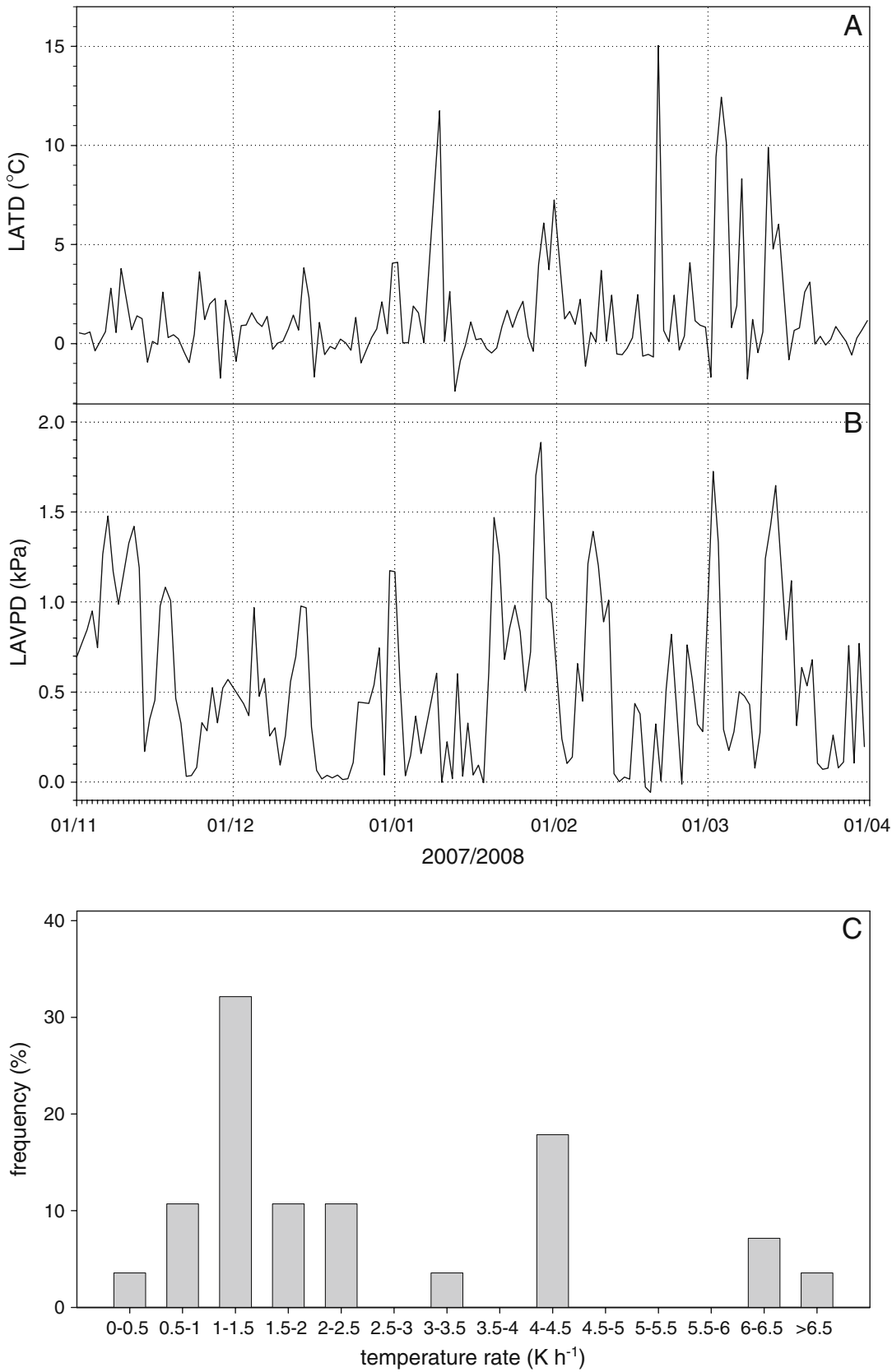
branches during several periods of winter 2001/2002 were significantly higher than those estimated for the period $1996 / 1997-2000 / 2001(P<0.05$, Fig. 5a), especially at the end of the winter (from February until April). Furthermore, the temperature showed a gradual increase from January until April during the previous 5 years, while there was a sharp temperature increase during the end of the winter and early spring of 2002 (Fig. 5a). Furthermore, between February and March, four periods with remarkably higher LATD occurred in winter 2001/2002 when compared with the estimation for the previous 5 years $(P<0.05$, Fig. $5 b)$.

Table 1 shows the estimated freeze-thaw cycles during winter in the period 1996/1997-2000/2001 and absolute number of freeze-thaw cycles estimated during winter 2001/2002 and measured during winter $2007 / 2008$ in south-exposed branches of the studied Scots pine population. Many freeze-thaw cycles were observed at the beginning of winter, while, during midwinter, the number of freeze-thaw events decreased. The highest number of freeze-thaw events was observed during December 2001/2002. In previous years, freeze-thaw events were most frequent in December and January. The total number of estimated freeze-thaw events was much higher during winter $2001 / 2002$ than in the previous five winters and similar to that measured during winter 2007/2008.

3.2 Water potential, hydraulic conductivity, embolism rates and anatomical measurements

Leaf water potential (megapascals) is almost always lower in trees affected by defoliation than in non-affected ones (Fig. 6). The differences are particularly marked during November 2005 and April 2006.

The relationship between branch diameter and hydraulic conductivity $\left(K_{\mathrm{h}}\right)$ for unaffected and nonaffected trees is shown in Fig. 7. $K_{\mathrm{h}}$ of unaffected trees follows the model proposed by Cochard (1992), whereas affected trees do not follow this pattern. The decrease found in $K_{\mathrm{h}}$ in affected trees suggests the existence of a certain degree of embolism, which is confirmed by measuring the loss of conductivity in south-exposed branches (Fig. 8).

Mean diameter of the tracheids is $12.5 \pm 0.1 \mu \mathrm{m}$ in the early wood, and mean hydraulic diameter of the tracheids is $15.0 \pm 0.1 \mu \mathrm{m}$, with no visible difference between affected and non-affected trees (data not shown).
Fig. 5 Estimated daily maximum a stem temperature (degrees Centigrade) and $\mathbf{b}$ leaf-to-air temperature difference (LATD, degrees Centigrade) during winter 2001/2002 and the previous 5 years (from $1996 / 1997$ to $2000 / 2001$ ) in south-exposed branches of the studied Scots pine population. The grey area gives the mean \pm SE temperature values of the previous 5 years

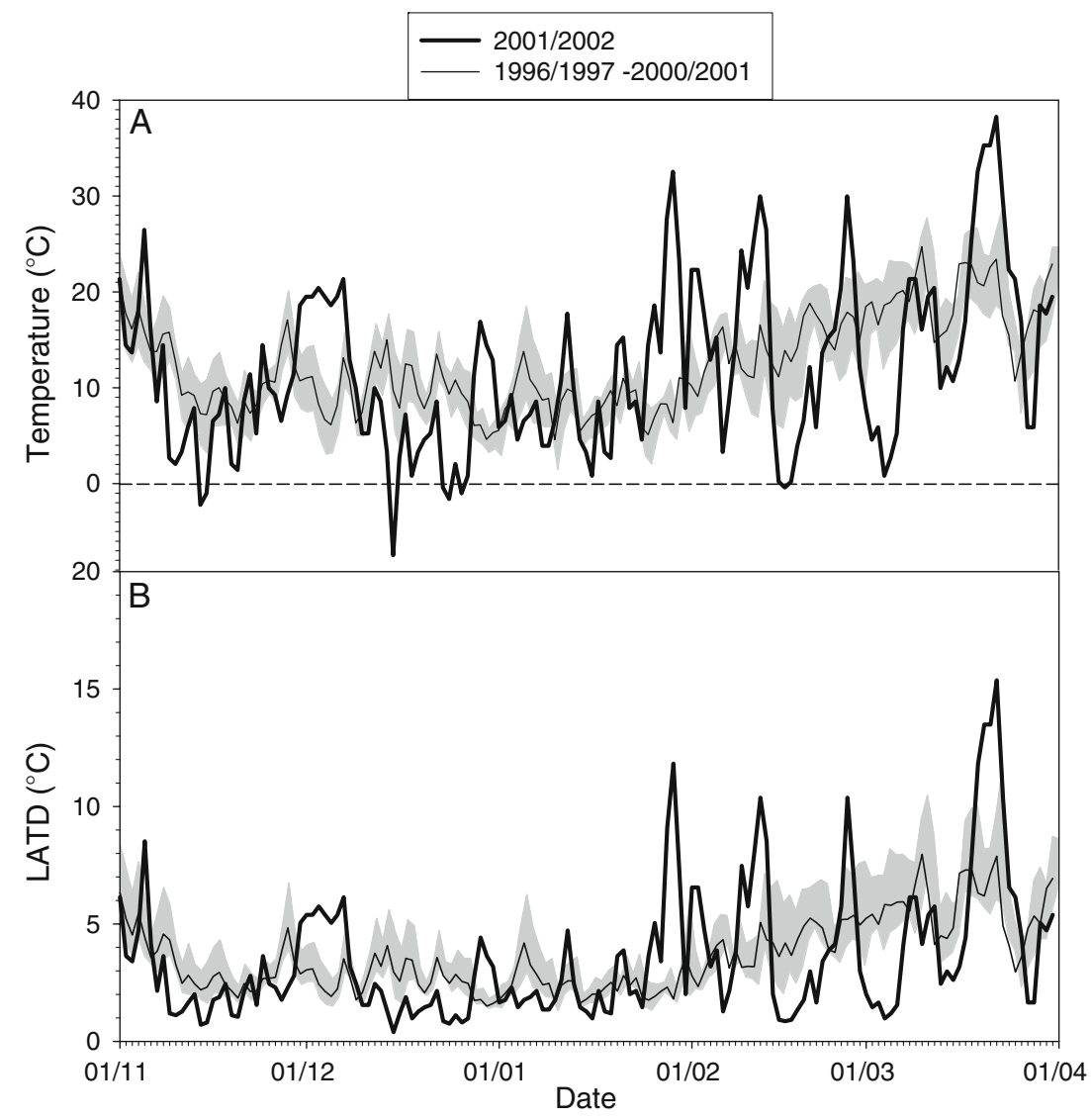


Table 1 Mean \pm SE number of estimated freeze-thaw cycles during winter in the period 1996/1997-2000/2001 and absolute number of freeze-thaw cycles estimated during winter 2001/2002 and measured during winter 2007/2008 in south-exposed branches of the studied Scots pine population

\begin{tabular}{|c|c|c|c|c|c|c|}
\hline Year & November & December & January & February & March & Winter \\
\hline 1996/1997-2000/2001 & $1.4 \pm 0.7$ & $5.2 \pm 1.8$ & $5.6 \pm 4.0$ & $2.4 \pm 1.3$ & $0.4 \pm 1.0$ & $15 \pm 5.6$ \\
\hline $2001 / 2002$ & 5 & 18 & 2 & 3 & 1 & 29 \\
\hline $2007 / 2008$ & 3 & 10 & 5 & 2 & 6 & 26 \\
\hline
\end{tabular}

Freezing events were counted when the stem temperatures decreased from above $0^{\circ} \mathrm{C}$ to below $-2^{\circ} \mathrm{C}$, while thawing events were counted when temperatures increased from lower than $-2^{\circ} \mathrm{C}$ above $0^{\circ} \mathrm{C}$ (Mayr et al. 2006). Correlations between measured temperatures (period 2006/2008) and the historical data from the nearby meteorological station (Villarroya de los Pinares, $40^{\circ} 31^{\prime} \mathrm{N}, 0^{\circ} 40^{\prime} \mathrm{W}, 1337$ m.a.s.l.) were established in order to estimate the temperatures in the studied Scots pine population during the period 1996/1997-2000/2001 and 2001/2002 (see section 2.3 for details)

\section{Discussion}

In this investigation, we analysed the possible connection between the microclimate conditions and the risk of xylem embolism during winter of 2001-2002. The high impairment of hydraulic conductivity found in the south-exposed branches of affected trees may agree with the symptoms described (needle browning followed by severe defoliation in the south face of the top). In principle, these symptoms could also be attributable to frost-induced damage ( $L u$ et al. 2003). However, Peguero-Pina et al. (2008) found that, in this population, the threshold value for frost damage in frost-hardened trees was ca. $-26^{\circ} \mathrm{C}$, which is much lower than the absolute minimum temperature estimated for the study site $\left(-17^{\circ} \mathrm{C}, 1995-2008\right.$ period). In this way, Climent et al. (2009) also found that the lethal temperature for $50 \%$ injury in needles from other Scots pine population located in the Iberian Peninsula $\left(40^{\circ} 51^{\prime} \mathrm{N}, 4^{\circ} 00^{\prime} \mathrm{W}, 1520\right.$ ma.s.1.) was lower than $-17^{\circ} \mathrm{C}$ (ca. $-21^{\circ} \mathrm{C}$ ).
The loss of hydraulic conductivity found in the affected trees (Figs. 7 and 8) could be due to the low water potential values measured during winter (Fig. 6). In fact, the values registered are close to the water potential corresponding to $50 \%$ loss of conductivity for Scots pine (Martínez-Vilalta and Piñol 2002). Embolism might, vice versa, also have impaired the plant water status and lowered the water potential of affected trees. However, because of the impaired water supply due to low or subzero soil temperatures (Fig. 3), we suggest that the effect of embolism in water supply could be much lower during winter than during summer.

Specifically, the water uptake in Scots pine is very limited when soil temperature is below $+8^{\circ} \mathrm{C}$ (Mellander et al. 2004), which occurs in this site during winter and early spring, both at 10 - and $20-\mathrm{cm}$ depth (Fig. 3). Therefore, any water loss during this period is difficult to recover. For this reason, winter transpiration, which is mainly attributed to non-stomatal water losses, can be
Fig. 6 Midday water potential (-megapascals) of southexposed branches from unaffected (without any symptom of defoliation) and affected (with evident symptoms of defoliation in the $\mathrm{S}$ face of the crown) trees of the studied Scots pine population, measured from August 2005 until November 2006. Data are mean $\pm \mathrm{SE}$

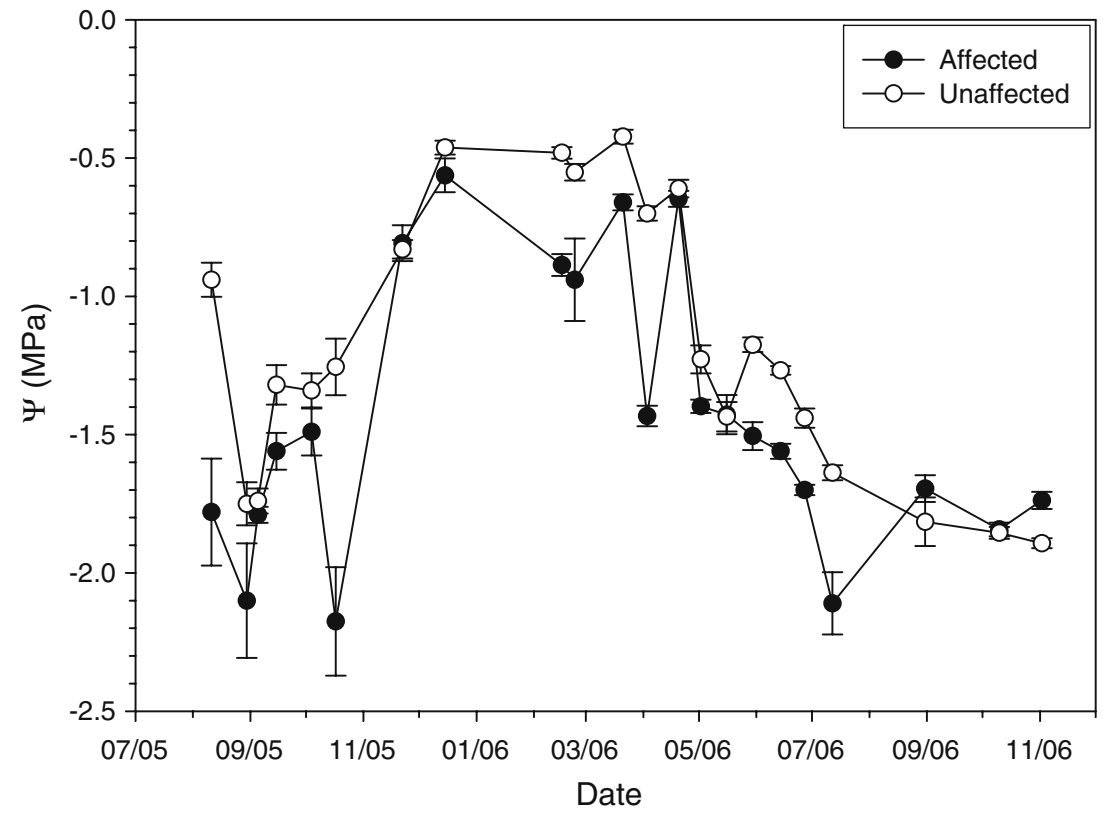


Fig. 7 Relationship between diameter (metres) and hydraulic conductivity (kilogramme metre per second per megapascal) of branches from unaffected (without any symptom of defoliation) and affected (with evident symptoms of defoliation in the $\mathrm{S}$ face of the crown) trees of the studied Scots pine population. The black line indicates the exponential relationship found for unaffected trees, which follows the exponential model proposed by Cochard (1992). The pictures show three sample cross-sections with contrasting values of percentage of loss of conductivity: $(A) 0 \%,(B) 48 \%$ and $(C) 95 \%$

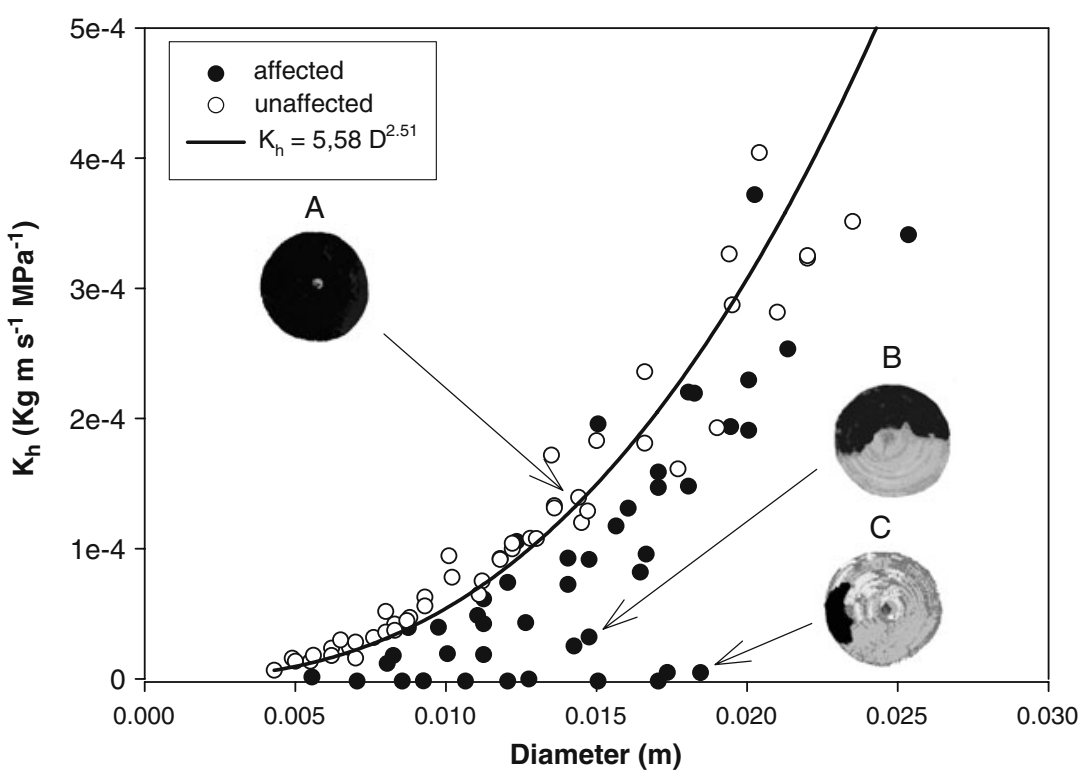

considered a crucial factor that can jeopardise tree survival (Hadley and Smith 1987). In fact, winter LAVPD (kilopascals), which is the driving force for transpiration, is much higher (Fig. 4b) than that stated by Grace (1990) for a northern Scots pine population (0.2 kilopascals). In this way, high solar radiation rates, which are common in this site during winter and early spring (Fig. 2c), increase air temperature (Fig. 2a) and LATD (Fig. 4a), leading to an increase in the LAVPD (Fig. 4b). It should be noted that high solar radiation episodes are associated with positive values of the NAO index (Pozo-Vázquez et al. 2004), which were especially high during winter 2001/2002 in relation to the previous five winters (Hurrel and Deser 2009). Thus, the combined effect of low soil temperatures (which limits water

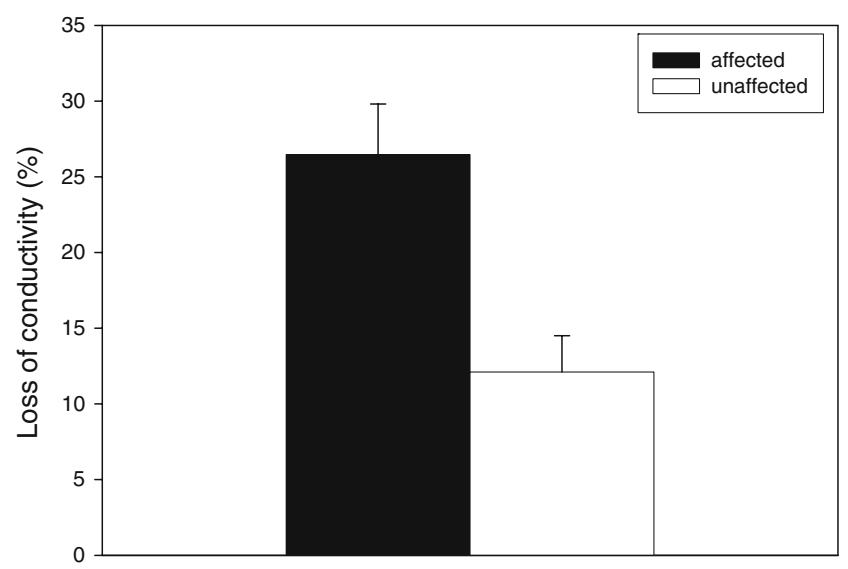

Fig. 8 Loss of conductivity (percent) for unaffected (without any symptom of defoliation) and affected (with evident symptoms of defoliation in the $\mathrm{S}$ face of the crown) trees of the studied Scots pine population. Data are mean \pm SE. Different letters indicate significant differences at $P<0.05$ uptake by roots) and high radiation events throughout the winter (which increases the loss of water by transpiration) probably caused low water potentials during winter in the studied Scots pine population. We suggest that the studied Scots pine population is living under environmental conditions very similar to those found in the timberline ecotone (Hadley and Smith 1987).

Moreover, the relatively high number of freeze-thaw events that may have occurred during winter 2001/2002 (Table 1) may have reduced the resistance of this Scots pine population to xylem cavitation (Mayr et al. 2006). In this way, Mayr et al. (2003a) showed that repeated freeze-thaw events caused embolism even in tracheids with smaller diameters than those found in the studied Scots pine population. Thus, according to the model of Pittermann and Sperry (2006), tracheids of P. sylvestris should be more vulnerable to embolism induced by repeated freeze-thaw cycles than those studied by Mayr et al. (2003a). The other factor that could have contributed to the induction of xylem embolism is the extraordinary rate in temperature change that characterises some of the recorded freeze-thaw events (Fig. 3). Thus, high thawing rates may limit the rate that gas bubbles can dissolve in the surrounding fluid (Feild and Brodribb 2001) and result in the formation of embolisms. In this way, the rates of temperature increase (Kelvin per hour) at days with freeze-thaw cycles are very similar to those reported for Picea abies (Mayr et al. 2006). Although freeze-thaw events can cause embolism by itself, we suggest that the occurrence of freeze-thaw events may have reduced the cavitation resistance of these Scots pine population. Thus, the existence of other factors such as low soil temperatures and high radiation events, which increased the loss of water by transpiration, could 
cause an additional decrease of water potential, which may induce embolism in a more vulnerable xylem.

We have characterised in this study several stress factors during winter and possible impairments at this extreme site, and we have estimated and compared microclimatic data of winter 2001/2002 and the previous five winters (from 1996-1997 to 2000-2001) to analyse parameters critical for plant water relations. Based on the data of winter 2007 , we therefore conclude that winter drought during 2001/2002 could have been critical for $P$. sylvestris. Although the embolism will not further impair winter water relations, it might influence the following vegetative period because summer drought in this site is noticeable up to the alpine zones.

Acknowledgements This study was supported by a specific collaboration agreement between CITA-Aragón and Departamento de Medio Ambiente-Gobierno de Aragón. Moreover, this study was partially supported by INIA project SUM2008-00004-C03 (Ministerio de Ciencia e Innovación). Financial support from Gobierno de Aragón (A54 research group) is also acknowledged.

\section{References}

Alía R, Moro-Serrano J, Notivol E (2001) Genetic variability of Scots pine (Pinus sylvestris) provenances in Spain: growth traits and survival. Silva Fenn 35:27-38

Andersson B, Fedorkov A (2004) Longitudinal differences in Scots pine frost hardiness. Silvae Genet 53:76-80

Anfodillo T, Pasqua Di Biscegile P, Urso T (2002) Minimum cuticular conductance and cuticle features of Picea abies and Pinus cembra needles along an altitudinal gradient in the Dolomites (NE Italian Alps). Tree Physiol 22:479-487

Breckle SW (2002) Walter's Vegetation of the Earth. The Ecological Systems of the Geo-biosphere. Springer-Verlag, Berlin

Cañellas I, Martínez-García F, Montero G (2000) Silviculture and dynamics of Pinus sylvestris L. stands in Spain. Inv Agrar Sist Rec Forest FS 1:233-253

Cheddadi R, Vendramin GG, Litt T, François L, Kageyama M, Lorentz S, Laurent JM, de Beaulieu JL, Sadori L, Jost A, Lunt D (2006) Imprints of glacial refugia in the modern genetic diversity of Pinus sylvestris. Glob Ecol Biogeogr 15:271-282

Climent J, Costa-Silva F, Chambel MR, Pardos M, Almeida MH (2009) Freezing injury in primary and secondary needles of Mediterranean pine species of contrasting ecological niches. Ann For Sci 66:407

Cochard H (1992) Vulnerability of several conifers to air embolism. Tree Physiol 11:73-83

Cochard H, Coll L, Le Roux X, Améglio T (2002) Unraveling the effects of plant hydraulics on stomatal closure during water stress in walnut. Plant Physiol 128:282-290

Feild TS, Brodribb T (2001) Trunk water transport and freeze-thaw xylem embolism in conifer and angiosperms in a Tasmanian treeline heath. Oecologia 127:314-320

Grace J (1990) Cuticular water loss unlikely to explain tree-line in Scotland. Oecologia 84:64-68

Hadley JL, Smith WK (1987) Influence of kummholz mat microclimate on needle physiology and survival. Oecologia 73:82-90

Hurrel JW, Deser C (2009) North Atlantic climate variability: the role of the North Atlantic Oscillation. J Mar Syst 78:28-41
Jarvis PG, James GB, Landsberg JJ (1976) Coniferous forest. In: Monteith JL (ed) Vegetation and the Atmosphere, vol II, Case Studies. Academic Press, London, pp 171-240

Lu P, Joyce DG, Sinclair RW (2003) Geographic variation in cold hardiness among eastern white pine (Pinus strobus L.) provenances in Ontario. For Ecol Manag 178:329-340

Martin TA, Hinckley TM, Meinzer FC, Sprugel DG (1999) Boundary layer conductance, leaf temperature and transpiration of Abies amabilis branches. Tree Physiol 19:435-443

Martínez-Vilalta J, Piñol J (2002) Drought-induced mortality and hydraulic architecture in pine populations of the NE Iberian Peninsula. For Ecol Manag 161:247-256

Mayr S, Cochard H (2003) A new method for vulnerability analysis of small xylem areas reveals that compression wood of Norway spruce has lower hydraulic safety than opposite wood. Plant Cell Environ 26:1365-1371

Mayr S, Wolfschwenger M, Bauer H (2002) Winter-drought induced embolism in Norway spruce (Picea abies) at the Alpine timberline. Physiol Plant 115:74-80

Mayr S, Gruber A, Bauer H (2003a) Repeated freeze-thaw cycles induce embolism in drought stressed conifers (Norway spruce, stone pine). Planta 217:436-441

Mayr S, Schwienbacher F, Bauer H (2003b) Winter at the alpine timberline: why does embolism occur in Norway spruce but not in stone pine? Plant Physiol 131:780-792

Mayr S, Wieser G, Bauer H (2006) Xylem temperatures during winter in conifers at the alpine timberline. Agric For Meteorol 137:8188

Mayr S, Cochard H, Améglio T, Kikuta SB (2007) Embolism formation during freezing in the wood of Picea abies. Plant Physiol 143:60-67

Mellander PE, Bishop K, Lundmark T (2004) The influence of soil temperature on transpiration: a plot scale manipulation in a young Scots pine stand. For Ecol Manag 195:15-28

Mellander PE, Stahli M, Gustafsson D, Bishop K (2006) Modelling the effect of low soil temperatures on transpiration by Scots pine. Hydrol Process 20:1929-1944

Peguero-Pina JJ, Morales F, Gil-Pelegrín E (2008) Frost damage in Pinus sylvestris L. stems assessed by chlorophyll fluorescence in cortical bark chlorenchyma. Ann For Sci 65:813

Pittermann J, Sperry JS (2003) Tracheid diameter is the key trait determining the extent of freezing-induced embolism in conifers. Tree Physiol 23:907-914

Pittermann J, Sperry JS (2006) Analysis of freeze-thaw embolism in conifers: the interaction between cavitation pressure and tracheid size. Plant Physiol 140:374-382

Poyatos R, Martínez-Vilalta J, Cermák J, Ceulemans R, Granier A, Irvine J, Köstner B, Lagergren F, Meiresonne L, Nadezhdina N, Zimmermann R, Llorens P, Mencuccini M (2007) Plasticity in hydraulic architecture of Scots pine across Eurasia. Oecologia 153:245-249

Poyatos R, Llorens P, Piñol J, Rubio C (2008) Response of Scots pine (Pinus sylvestris L.) and pubescent oak (Quercus pubescens Willd.) to soil and atmospheric water deficits under Mediterranean mountain climate. Ann For Sci 65:306

Pozo-Vázquez D, Tovar-Pescador J, Gámiz-Fortis SR, Esteban-Parra MJ, Castro-Díez Y (2004) NAO and solar radiation variability in the European North Atlantic Region. Geophys Res Lett 31:L05201

Querol JV (1995) Ecogeografía y explotación forestal en las serranías de Albarracín y Gúdar-Maestrazgo. Consejo de Protección de la Naturaleza de Aragón, Zaragoza, 280 p

Schwarz PA, Fahey TJ, Dawson TE (1997) Seasonal air and soil temperature effects on photosynthesis in red spruce (Picea rubens) saplings. Tree Physiol 17:187-194

Turner NC (1988) Measurement of plant water status by the pressure chamber technique. Irrig Sci 9:289-308 